\title{
DORA-julistus (San Francisco Declaration on Research Assessment)
}

\author{
Susanna Nykyri \\ Tampereen teknillinen yliopisto \\ susanna.nykyri@tut.fi \\ https://orcid.org/0000-0002-5018-5176 \\ Asiasanat: DORA-julistus; San Francisco Declaration on Research Assessment; tutkimustoiminta; arviointi; \\ arviointimenetelmät
}

Rahoittajien, akateemisten instituutioiden ja muiden osapuolten tapoihin arvioida tieteellisen tutkimustoiminnan tuotoksia kohdistuu pakottava kehittämistarve. Tähän tarttui joukko tiedelehtien toimittajia ja kustantajia, kun he tapasivat amerikkalaisen solubiologian yhdistyksen (The American Society for Cell Biology, ASCB) vuosikokouksessa San Franciscossa (Kalifornia) 16.12.2012. Ryhmä kehitti joukon suosituksia, joka nimettiin San Francisco Declaration on Research Assessment (DORA-julistukseksi). Kutsumme kaikkia kiinnostuneita osapuolia kaikilta tieteenaloilta ilmaisemaan tukensa allekirjoittamalla tämä julistus. $^{1}$

Tieteellisen tutkimuksen tuotokset ovat moninaisia ja erilaisia. Niitä ovat uutta tietoa raportoivat tutkimusartikkelit, data, reagenssit ja ohjelmistot; immateriaaliomaisuus; sekä korkeasti koulutetut nuoret tieteentekijät. Rahoittajilla, tutkijoita palkkaavilla instituutioilla ja tutkijoilla itsellään on halu ja tarve arvioida tieteellisten tuotosten laatua ja vaikuttavuutta. Onkin välttämätöntä, että tieteellisiä tuotoksia mitataan oikein ja arvioidaan viisaasti.

1 Suomennos on julkaistu DORAn sivuilla 21.10.2018 (https://sfdora.org/read/fi/). Susanna Nykyri kiittää lämpimästi Anna Hatchia erinomaisesta yhteistyöstä ja käännöksen aiempaa versiota kommentoineita Maria Forsmania ja Anne Lehtoa arvokkaasta avustaan. 
Lehtien vaikuttavuuskerrointa (Journal Impact Factor) käytetään säännöllisesti ensisijaisena parametrina vertailtaessa yksilöiden ja instituutioiden tieteellisiä tuotoksia. Vaikuttavuuskerroin, kuten Thomson Reuters ${ }^{2}$ sen laski, kehitettiin alun perin kirjastonhoitajia varten lehtihankintojen valinnan apuvälineeksi, ei siis yksittäisten artikkeleiden tieteellisen laadun arviointiin. Tämä on hyvä pitää mielessä, ja tärkeää on ymmärtää, että lehden vaikuttavuuskertoimella on tutkimuksen arvioinnin välineenä lukuisia puutteita. Näihin rajoituksiin kuuluu:

a. viittausten jakaumat lehden artikkelien kesken ovat erittäin vääristyneitä $[1,2,7]$

b. vaikuttavuuskertoimen ominaisuudet ovat tieteenalasidonnaisia: artikkelityypit ovat hyvin erilaisia ja moninaisia, ja niihin kuuluu alkuperäisiä tutkimusartikkeleita ja katsauksia $[1,11]$

c. vaikuttavuuskertoimia voidaan manipuloida (tai vehkeillä) toimitusmenettelytavoilla [9]

d. vaikuttavuuskertoimien laskennassa käytetty data ei ole läpinäkyvää eikä avoimesti kaikkien saatavana $[4,5,11]$.

Alla on esitetty joukko suosituksia, joiden avulla tieteellisten tuotosten arvioinnin laatua voidaan parantaa. Tulevaisuudessa tutkimuksen vaikuttavuuden arvioinnissa muiden tuotosten kuin tutkimusartikkeleiden merkitys kasvaa, mutta vertaisarvioidut tieteelliset artikkelit tulevat säilymään keskeisenä tutkimustuotoksena tutkimuksen arvioinnissa. Niinpä suosituksemme keskittyy pääasiassa niihin käytäntöihin, jotka liittyvät vertaisarvioiduissa lehdissä julkaistuihin tutkimusartikkeleihin, mutta niitä voidaan ja pitäisikin käyttää myös muiden tuotosten tunnistamisessa, kuten datasettien, jotka ovat tärkeitä tutkimuksen tuotoksia. Nämä suositukset on suunnattu rahoittajille, akateemisille instituutioille, lehdille, metriikkaa harjoittaville organisaatioille sekä yksittäisille tutkijoille. Suosituksiin sisältyy useita yhteisiä teemoja:

- tarve välttää rahoitus-, nimitys- ja ylennyspäätöksissä artikkeleiden julkaisukanavaan pohjautuvan metriikan, kuten vaikuttavuuskertoimen (Journal Impact Factor), käyttöä

- tarve arvioida tutkimusta ennemmin sen omiin ansioihin perustuen kuin sen perusteella, missä lehdessä se on julkaistu; ja

- tarve hyödyntää verkkojulkaisemisen tarjoamia mahdollisuuksia (kuten väljentää tarpeettomia artikkelien sana-, kuva- ja viittausmäärien rajoi- 
tuksia, sekä tutkia uusia merkittävyyden ja vaikuttavuuden indikaattoreita).

Me tunnistamme, että monet rahoittajat, instituutiot, kustantajat ja tutkijat jo edistävät tutkimuksen arvioinnin parempia käytäntöjä. Nämä askeleet ovat tärkeä alku vauhdittamaan muutosta kohti kehittyneempiä ja tarkoituksenmukaisempia tutkimuksen arvioinnin menettelytapoja, joita nyt kaikki sidosryhmät voivat yhdessä kehittää ja omaksua.

DORA-julistuksen allekirjoittajat tukevat seuraavien tutkimuksen arvioinnin käytäntöjen omaksumista.

\section{Yleinen suositus}

1. Älä käytä lehtiperustaista metriikkaa, kuten lehtien vaikuttavuuskertoimia, yksittäisen tutkimusartikkelin laadun mittaamisen korvikkeena arvioidaksesi yksittäisen tutkijan tieteellisiä ansioita, tai rekrytointi-, ylennys- ja rahoituspäätöksissä.

\section{Rahoittajille}

2. Määrittele avoimesti ja selkeästi kriteerit, joiden perusteella rahoituksen hakijoiden tieteellistä tuottavuutta arvioidaan, ja korosta erityisesti aloitteleville arvioijille, että kirjoituksen tieteellinen sisältö on paljon tärkeämpi kuin julkaisumetriikka tai artikkelin julkaisseen lehden maine.

3. Ota tutkimuksen arvioinnissa tutkimusjulkaisujen lisäksi huomioon kaikkien tutkimustuotosten (sisältäen datasetit ja ohjelmistot) arvo ja vaikuttavuus. Harkitse laajaa kirjoa vaikuttavuusmittareita, mukaan lukien laadulliset vaikuttavuusindikaattorit, kuten vaikutus politiikkaan ja käytäntöön.

\section{Korkeakouluille ja tiedelaitoksille}

4. Määrittele rekrytointi-, urapolku- ja ylennyspäätöksissä käytetyt kriteerit avoimesti ja selkeästi, ja korosta erityisesti aloitteleville arvioijille, että artikkelin tieteellinen sisältö on paljon tärkeämpi kuin julkaisumetriikka tai kirjoituksen julkaisseen lehden maine.

5. Ota tutkimuksen arvioinnissa tutkimusjulkaisujen lisäksi huomioon kaikkien tutkimustuotosten (sisältäen datasetit ja ohjelmistot) arvo ja vaikuttavuus. Harkitse laajaa kirjoa vaikuttavuusmittareita, mukaan lukien laadulliset vaikuttavuusindikaattorit, kuten vaikutus politiikkaan ja käytäntöön. 


\section{Kustantajille}

6. Supista merkittävästi lehden vaikuttavuuskertoimen merkitystä mainontavälineenä. Ihanteellinen ratkaisu on lakata käyttämästä vaikuttavuuskerrointa tai käyttää julkaisupohjaista metriikkaa monipuolisesti (esim. 5-vuoden vaikuttavuuskerroin, EigenFactor [3], SCImago [6], h-indeksi, toimitustyö- tai julkaisukerrat jne), mikä tarjoaa monipuolisemman käsityksen lehden saavutuksista.

7. Tarjoa valikoima artikkelipohjaista metriikkaa ja rohkaise siten siirtymistä julkaisukanavaan perustuvasta metriikasta arviointiin, joka perustuu tieteellisen artikkelin sisältöön.

8. Rohkaise vastuullista tekijyyskäytäntöä ja jokaisen tekijän osallisuuden määrittelyä ja julkituomista.

9. Riippumatta siitä, ilmestyykö lehti avoimena vai tilauspohjaisena, poista kaikki lähdeluetteloiden uudelleen- ja jälleenkäyttörajoitukset ja tarjoa ne saataville Yleismaailmallisella Public Domain -lausumalla [8].

10. Antaaksesi kunnian tutkimustuloksia ensin raportoineille poista tai vähennä tutkimusartikkeleiden viitemäärien rajoituksia, ja kun sopivaa, niin vaadi käyttämään alkuperäislähteistöä katsausten asemasta.

\section{Metriikkaa tuottaville organisaatioille}

11. Toimi avoimesti ja läpinäkyvästi avaamalla kaikki metriikassa käytetty data ja menetelmät.

12. Avaa data sellaisella lisenssillä, joka sallii rajoituksettoman uudelleen- ja jälleenkäytön, ja kun mahdollista, niin tarjoa dataan koneellinen pääsy.

13. Tee selväksi, että metriikan epäasiallista manipulointia ei suvaita; ilmaise selkeästi mikä on epäasiallista manipulointia ja mitä menetelmiä sen estämiseksi otetaan käyttöön.

14. Kun metriikkaa käytetään, kootaan tai vertaillaan, selvitä artikkelityyppien hajonta (esim. katsaukset versus tutkimusartikkelit) tieteenalakohtaisesti. 


\section{Tutkijoille}

15. Osallistuessasi rahoituksesta, rekrytoinnista, urapolusta tai ylentämisestä päättäviin elimiin, perusta arviointisi ennemmin tieteellisiin sisältöihin kuin julkaisumetriikkaan.

16. Viittaa aina kun se on tarkoituksenmukaista alkuperäiskirjallisuuteen, jossa havainnot on ensimmäiseksi raportoitu, äläkä niihin, jotka ovat viitanneet alkuperäislähteisiin. Näin annat kunnian sille, kenelle se kuuluu

17. Käytä lausunnoissasi ja suosituksissasi monipuolisesti artikkeliperustaista metriikkaa näyttönä yksittäisten julkaistujen artikkeleiden ja muiden tutkimustuotosten vaikuttavuudesta [10].

18. Haasta tutkimuksen arvioinnin käytännöt, jotka pohjautuvat asiaankuulumattomasti lehtien vaikuttavuuskertoimiin, ja edistä ja opeta parhaita käytäntöjä, jotka keskittyvät tutkimustuotosten arvoon ja vaikuttavuuteen.

\section{Viitteet}

1. Adler, R., \& Ewing, P., J.and Taylor. (2008). Citation statistics. A report from the International Mathematical Union. https://www.mathunion.org/fileadmin/IMU/Report/ Citationstatistics.pdf

2. Editorial. (2005). Not-so-deep impact. Nature, 435(7045), 1003-1004. https://doi.org/10. 1038/4351003b

3. Eigenfactor: Revealing the Structure of Science. (ei pvm.-). http://www. eigenfactor.org/

4. Rossner, M., Epps, H. V., \& Hill, E. (2008). Irreproducible results: a response to Thomson Scientific. The Journal of Cell Biology, 180(2), 254-255. https://doi.org/10.1083/jcb. 200801036

5. Rossner, M., Epps, H. V., \& Hill, E. (2008). Show me the data. The Journal of General Physiology, 131(1), 3-4. https://doi.org/10.1085/jgp. 200709940

6. Scimago Journal \& Country Rank. (ei pvm.-). https://www.scimagojr.com/

7. Seglen, P. O. (1997). Why the impact factor of journals should not be used for evaluating research. BMJ : British Medical Journal, 314(7079), 498-502. https://www.ncbi.nlm.nih.gov/ pmc/articles/PMC2126010/

8. Shotton, D. (2013). Open letter to publishers. OpenCitations. https://opencitations. wordpress.com/2013/01/03/open- letter-to-publishers/

9. The PLoS Medicine Editors. (2006). The impact factor game. PLOS Medicine, 3(6), e291. https: //doi.org/10.1371/journal.pmed.0030291

10. Tools - altmetrics.org. (ei pvm.-). http://altmetrics.org/tools/

11. Vanclay, J. K. (2012). Impact factor: outdated artefact or stepping-stone to journal certification? Scientometrics, 92(2), 211-238. https://doi.org/10.1007/s11192-011-0561-0 